\title{
Preemptive analgesia of dexamethasone as compared to ketorolac tromethamine in simple tooth extractions*
}

\author{
Analgesia preemptiva da dexametasona em relação ao cetorolaco de trometamol em extrações \\ dentárias simples
}

Rodrigo Mathias Freire de Menezes Carneiro', Rafael Soares da Cunha², Liane Maciel de Almeida Souza², Francisco Groppo ${ }^{3}$

${ }^{*}$ Received from the Department of Surgery I, Federal University of Sergipe, Aracaju, SE, Brazil.

DOI 10.5935/1806-0013.20140034

\section{ABSTRACT}

BACKGROUND AND OBJECTIVES: Understanding that pain is the most important postoperative problem, in face to the need of establishing a therapeutic protocol to control post-tooth extraction pain and due to few studies comparing these drugs is that our study is justified. This study aimed at evaluating and at comparing the preemptive analgesic effect of two drugs, both administered in bolus.

METHODS: This is an experimental research as from a clinical trial with human beings. It is a double-blind, crossover and randomized trial with 51 patients seen by the Oral Surgery Ambulatory of the Dentistry Department, Federal University of Sergipe (DOD/UFS), between September 2011 and September 2012, who needed simple alveolar extractions in different hemiarcades, using dexamethasone (4mg) or ketorolac tromethamine $(10 \mathrm{mg})$, one hour before surgery distinctively. Pain was evaluated in the first 24 and 48 hours with the visual analog scale. The interval of eight days was established between extractions.

RESULTS: There have been no statistically significant differences by Fisher $(p>0.05)$ and Friedman $(p>0.05)$ Exact tests, or between drugs (considering a same period) or between periods (considering the same drug).

CONCLUSION: There are no significant differences between drugs and observed periods.

Keywords: Dexamethasone, Ketorolac tromethamine, Preemptive analgesia.

1. Pindamonhangaba College, Pindamonhangaba, SP, Brazil.

2. Federal University of Sergipe, Aracaju, SE, Brazil.

3. State University of Campinas, School of Dentistry, Piracicaba, SP, Brazil.

Submitted in November 20, 2013.

Accepted for publication in April 04, 2014.

Conflict of interests: none.

Correspondence to:

Rodrigo Mathias Freire de Menezes Carneiro

Rua Deodoro dos Santos, 22, Conj. Montal - Bairro Luzia

49045-390 Aracaju, SE, Brasil.

E-mail: rodrigo.mathias2489@gmail.com

(C) Sociedade Brasileira para o Estudo da Dor

\section{RESUMO}

JUSTIFICATIVA E OBJETIVOS: Entendendo que a dor é o maior transtorno pós-operatório, diante da necessidade de estabelecer um protocolo terapêutico do seu controle pósexodontias e dos poucos estudos comparando esses fármacos é que se justifica o trabalho. $\mathrm{O}$ objetivo deste estudo foi avaliar e comparar o efeito analgésico preemptivo de dois fármacos, ambos administrados em dose única.

MÉTODOS: A pesquisa tem caráter experimental a partir de um ensaio clínico com seres humanos. Trata-se de estudo duplamente encoberto, cruzado e randomizado, com 51 pacientes atendidos no Ambulatório de Cirurgia Oral do Departamento de Odontologia da Universidade Federal de Sergipe (DOD/UFS), entre setembro de 2011 e setembro de 2012, que necessitaram de extraçóes simples por via alveolar em hemiarcadas diferentes utilizando dexametasona $(4 \mathrm{mg})$ e cetorolaco de trometamol $(10 \mathrm{mg})$, uma hora antes da cirurgia distintamente. A dor foi avaliada nas primeiras 24 e 48h, com o uso da escala analógica visual. O intervalo de 8 dias foi estabelecido entre as exodontias.

RESULTADOS: Não houve diferenças estatisticamente significantes no teste Exato de Fisher $(p>0,05)$ e Friedman $(p>0,05)$, nem entre os fármacos (considerando um mesmo período) nem entre os períodos (considerando o mesmo fármaco).

CONCLUSÃO: Não existem diferenças significativas entre os fármacos e os períodos observados.

Descritores: Analgesia preemptiva, Cetorolaco de trometamol, Dexametasona.

\section{INTRODUCTION}

Pain is a biological phenomenon important for body defense, but uncomfortable for affected individuals. It is inherent to some dental procedures, especially surgical procedures, being its intensity often related to surgery extension ${ }^{1}$. According to Kissin ${ }^{2}$, postoperative pain control in dentistry, by means of preemptive analgesia, is an antinociceptive treatment to prevent the altered processing of an afferent input, which would amplify postoperative pain.

Preemptive analgesia has four major objectives: decrease acute pain induced by surgical trauma, both in the intraop- 
erative and postoperative periods; prevent the establishment of neural plasticity mechanisms of the central system responsible for referred and chronic pain ("memory of pain"); inhibition of persistent postoperative pain; and development of chronic pain ${ }^{3}$.

There are basically three major groups of drugs used to control postoperative pain: steroid anti-inflammatory drugs, non-steroid anti-inflammatory drugs (NSAIDs) and central and peripheral action analgesics. These drugs promote similar pharmacological results; however, each one has different indications and acts in a different pain mechanism stage ${ }^{4}$.

Steroids may be defined as synthetic hormones mimicking actions of endogenous cortisol secreted by the adrenal gland. Their therapeutic effects are in general attributed to the suppression of multiple mechanisms involved in the inflammatory response, leading to a decrease in pro-inflammatory chemical mediators levels at injury site ${ }^{5}$.

According to the National Agency of Sanitary Surveillance $(\text { ANVISA) })^{6}$, ketorolac tromethamine is a potent analgesic agent of the NSAIDs class, also with anti-inflammatory and antipyretic effects. Its action mechanism is through the inhibition of the cyclooxygenase enzymatic system and, as a consequence, of prostaglandins synthesis. It may be considered an analgesic with peripheral activity. The drug has no sedative or anxiolytic properties.

Authors ${ }^{7}$ have evaluated the efficacy of ketorolac tromethamine preemptive analgesia after third molar extraction. Intravenous ketorolac tromethamine $(30 \mathrm{mg})$ was administered immediately before surgery in one group and immediately after surgery in the other. The conclusion was that ketorolac administered before surgery has induced postoperative analgesia of up to 8-9h after surgery, when patients needed rescue analgesics for postoperative pain. For the other group, the mean was $6-9 \mathrm{~h}$ to begin consuming rescue analgesics. Preemptive ketorolac was better as compared to its administration after surgery ${ }^{7}$.

Understanding that pain is the most important postoperative problem and given the need to establish a therapeutic protocol to control post-tooth extraction pain, in addition to few studies in the literature with ketorolac tromethamine, is that our study is justified.

This study aimed at evaluating and at comparing the preemptive analgesic effect of dexamethasone and ketorolac tromethamine, both administered in bolus.

\section{METHODS}

This is an experimental study as from a clinical trial with human beings. It is a double-blind, crossover and randomized study.

Participated in the study 51 patients seen by the Ambulatory of Oral Surgery, Department of Dentistry, Federal University of Sergipe (DOD/UFS), from September 2011 to September 2012, who needed alveolar extractions in different hemiarcades.

Each patient was individually addressed and the importance of the research was explained. Those who agreed to participate have signed the Free and Informed Consent Term (FICT).

After signing the FICT, patients were individually referred to a waiting room where the first researcher delivered one of the studied drugs, dexamethasone $(4 \mathrm{mg})$ or ketorolac tromethamine $(10 \mathrm{mg})$, which were manipulated in pharmacy so that patients and remaining researchers could not identify them. Only the first researcher had such information.

For research purposes, it was established that dexamethasone $(4 \mathrm{mg}$ ) would be drug A and ketorolac tromethamine $(10 \mathrm{mg})$ would be drug B. So, the clinical record was filled as follows: first procedure drug $\mathrm{A}$ and second procedure drug $\mathrm{B}$, or vice-versa. Patient was referred to the surgeon, who performed the extractions according to Marzola and ToledoFilho protocol ${ }^{8}$.

All patients were anesthetized with $2 \%$ lidocaine hydrochloride, with 1:100.000 epinephrine, not exceeding two tubetes, according to Reed, Malamed and Fonner proto$\mathrm{col}^{9}$. After extraction, patients were fully informed about postoperative care and were asked to return $24 \mathrm{~h}$ after. After $24 \mathrm{~h}$, the third researcher has evaluated the analgesic efficacy of the drug through the $10-\mathrm{cm}$ visual analog scale (VAS), where zero means no pain and 10 unbearable pain. Patients have recorded in the scale their level of sensitivity and whether there has been the need to have the rescue analgesic paracetamol $(750 \mathrm{mg})$.

Patients were then asked to return $48 \mathrm{~h}$ after $\left(2^{\text {nd }}\right.$ postoperative day) for new evaluation of pain intensity with VAS and to check whether there had been the need for rescue drug. Eight days after the first procedure, patients returned to remove stitches and to be submitted to new extraction with the other drug to be tested ( $\mathrm{A}$ or $\mathrm{B}$, as the case might be). All procedures were recorded in clinical cards duly developed for the research.

After collection, data were tabulated and submitted to the following statistical tests: Friedman test with $\mathrm{p}<0.05$ and Fisher Exact test with $\mathrm{p}<0.05$.

This study was approved by the Ethics and Research Committee, Federal University of Sergipe (UFS), protocol CEP 257/2011 and $\mathrm{N}^{\circ}$ CAAE - 0223.0.107.000-2011.

\section{RESULTS}

The research was carried out with 51 patients, being 29 females and 22 males with mean age of 29.57 years.

Figure 1 shows VAS values obtained as a function of drugs. There have been no statistically significant differences (Friedman, p $>0.05$ ) between periods or drugs. So, there have been no differences between ketorolac and dexamethasone. Table 1 shows the use of paracetamol as a function of the drug and usage period.

There have been no statistically significant differences (Fisher Exact test, $\mathrm{p}>0.05$ ) between drugs (considering the same period) or between periods (considering the same drug). 


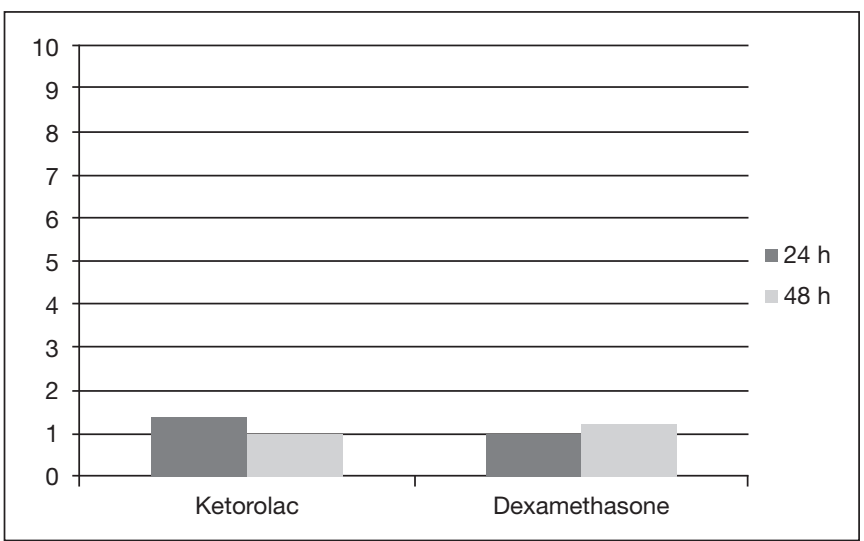

Figure 1. Mean and standard error of the visual analog scale (in $\mathrm{cm}$ ) as a function of the drug used

Table 1. Use of paracetamol as a function of the drug and usage period.

\begin{tabular}{lccccc}
\hline & \multicolumn{2}{c}{ Ketorolac } & \multicolumn{2}{c}{ Dexamethasone } \\
\hline Use & of & $24 \mathrm{~h}$ & $48 \mathrm{~h}$ & $24 \mathrm{~h}$ & $48 \mathrm{~h}$ \\
paracetamol & & & & \\
No & $47(92.15 \%)$ & $48(94.11 \%)$ & $48(94.11 \%)$ & $48(94.11 \%)$ \\
Yes & $4(7.85 \%)$ & $3(5.89 \%)$ & $3(5.89 \%)$ & $3(5.89 \%)$ \\
\hline
\end{tabular}

\section{DISCUSSION}

Postoperative pain control is a concern for dentists and the search for pharmacological protocols to decrease the problems caused by more invasive interventions has been constant. However, there is major controversy about which drug to use and how to administer it. In this sense, there are three therapeutic lines: one advocating the use of preoperative drugs, one using drugs in the postoperative period only, and one that uses them in the pre, intra and postoperative periods.

Preemptive analgesia is becoming one of the most promising strategies to pharmacologically treat pain ${ }^{3}$.

A study ${ }^{10}$ states that steroids, such as dexamethasone and betamethasone, are drugs which prevent nociceptors sensitization by phospholipase A2 inhibition. In addition, these are drugs of choice for dentistry and have some advantages as compared to cyclooxygenase inhibitors, among them: do not have significant adverse effects, do not interfere with hemostasis and inhibit leukotriens synthesis. Their dosage is single preoperative dose and their cost-benefit ratio is better, because in a single dose they do not delay healing.

As to dexamethasone, clinical trials have shown that a single preoperative dose may effectively decrease inflammatory responses after oral surgeries ${ }^{11}$. This was the reason why this drug was chosen as comparison standard for this research.

As to analgesic efficacy, ketorolac tromethamine has shown to be more potent among different NSAIDs under similar experimental conditions ${ }^{11}$ Ketorolac has also been used in association with opioids, as adjuvant, to decrease their consumption and common adverse effects, such as respiratory depression, itching, urinary retention, sedation and nausea ${ }^{12}$. So, supported by the literature, this research has adopted this drug to be tested and compared to dexamethasone.

In the postoperative period of oral surgeries, single and multiple 10 and $20 \mathrm{mg}$ ketorolac tromethamine doses were administered and both doses were equally effective, but were better than acetaminophen $(600 \mathrm{mg})$ with codeine ${ }^{13}$. Such data confirm our study results where ketorolac tromethamine $(10 \mathrm{mg})$ in single dose was effective to relieve pain in $92.15 \%$ of patients in the first $24 \mathrm{~h}$ and in $94.11 \%$ in $48 \mathrm{~h}$, with no need for rescue analgesics.

Dionne et al. ${ }^{14}$ have compared dexamethasone and placebo and dexamethasone and ketorolac. Authors have concluded that dexamethasone has decreased inflammation elements in the surgical area (prostaglandins and thromboxanes) without any effect on postoperative pain. However, ketorolac tromethamine has significantly decreased pain, and also prostaglandin and thromboxanes levels at surgery site. However, in our study, dexamethasone (4 $\mathrm{mg}$ ) as compared to ketorolac $(10 \mathrm{mg})$ has promoted similar analgesia. Our results confirm the study by Dionne et al. ${ }^{14}$ where ketorolac and dexamethasone have induced similar analgesia. In the first 24 and 48 h, analgesia was approximately $94.11 \%$ for dexamethasone and for ketorolac tromethamine approximately $92.5 \%$ in the first $24 \mathrm{~h}$ and $94.11 \%$ in $48 \mathrm{~h}$ with no need for paracetamol.

\section{CONCLUSION}

Based on our results and their correlation with literature review data, one may conclude that dexamethasone and ketorolac tromethamine one hour before surgery in single dose, used separately, were effective to control postoperative inflammatory pain. There were no significant differences between drugs in the observed periods.

\section{REFERENCES}

1. Fattah CM, Aranega AM, Leal CR, Martinho J, Costa AR. Controle da dor pós-operatória em cirurgia bucal: revisão de literatura. Rev Odontol Araçatuba. 2005;26(2):56-62.

2. Kissin I. Preemptive analgesia. Anesthesiology. 2000;93(4):1138-43.

3. Grape $S$, Tramèr MR. Do we need preemptive analgesia for the treatment of postoperative pain? Best Prac Res Clin Anaesthesiol. 2007;21(1):51-63.

4. Dejean JS, Santos IR, Andrade FV, Souza LM. Analgesia preemptiva em odontologia. Publ UEPG Biol Health Sci. 2008;14(2):23-30.

5. Bridgman JB, Gillgrass TG, Zacharias $M$. The absence of any pre-emptive analgesic effect for non-steroidal anti-inflammatory drugs. Br J Oral Maxillofac Surg. 1996;34(5):428-31.

6. Agencia Nacional de Vigilância Sanitária (Brasil). Bulário eletrônico [Internet]. Brasília: Ministério da Saúde; 2005 [citado 15 de setembro 2012]. Available from http:// www4.anvisa.gov. br/BularioEletronico/.

7. Ong KS, Seymour RA, Chen FG, Ho VC. Preoperative ketorolac has a preemptive effect for postoperative third molar surgical pain. Int J Oral Maxillofac Surg. 2004;33(8):771-6.

8. Marzola C, Toledo-Filho JL. A extraçăo de dentes irrompidos - mecânica da exodontia com extratores. Rev Odontologia, Bauru, SP. 2014;14(1):53-72.

9. Reed KL, Malamed SF, Fonner AM. Local anesthesia part 2: technical considerations. Anesth Prog. 2012;59(3):127-36.

10. Andrade ED. Terapêutica medicamentosa em odontologia. 2a ed. Editora Artes Médicas; 2006. 47-59p. 
11. Leone M, Richard O, Antonini F, Rosseau S, Chabaane W, Guyot L, et al. Comparison of methylprednisolone and ketoprofen after multiple third molar extractions: a randomized controlled study. Oral Surg Oral Med Oral Pathol Oral Radiol Endod. 2007;103(1):e7-9.

12. Patrocínio LG, Rangel MO, Miziara GS, Rodrigues AM, Patrocínio JA, Patrocínio TG. Estudo comparativo entre cetorolaco e cetoprofeno no controle da dor pós-ope- ratória de uvulopalatofaringoplastia. Rev Bras Otorrinolaringol. 2007;73(3):339-42. 13. Ong KS, Tan JM. Preoperative intravenous tramadol versus ketorolac for preventing postoperative pain after third molar surgery. Int J Oral Maxillofac Surg. 2004;33(3):274-8.

14. Dionne RA, Gordon SM, Rowan J, Kent A, Brahim JS. Dexamethasone suppresses peripheral prostanoid levels without analgesia in a clinical model of acute inflammation. J Oral Maxillofac Surg. 2003;61(9):997-1003. 